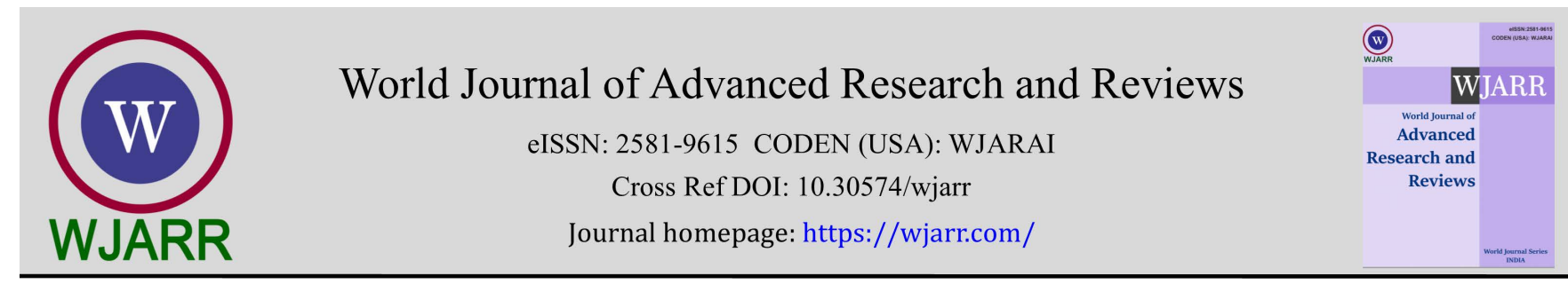

(RESEARCH ARTicle)

\title{
The importance of physical activity in COVID-19 times
}

\author{
Rodrigo Iván Aguilar-Enríquez ${ }^{1}$, Antonio Rivera ${ }^{2,}{ }^{*}$, Benjamín Flores-Chico ${ }^{1}$, Luis Enrique López de la Rosa \\ 1 and Yara Lorena Fernández-Montiel ${ }^{1}$ \\ ${ }^{1}$ Facultad de Cultura Física de la Benemérita Universidad Autónoma de Puebla, México. \\ ${ }^{2}$ Centro de Investigaciones en Ciencias Microbiológicas de la Benemérita Universidad Autónoma de Puebla, México.
}

World Journal of Advanced Research and Reviews, 2021, 09(03), 204-214

Publication history: Received on 08 February 2021; revised on 11 March 2021; accepted on 14 March 2021

Article DOI: https://doi.org/10.30574/wjarr.2021.9.3.0096

\begin{abstract}
The COVID-19 pandemic altered activities of societies, forced closures at the national level in several countries, populations had to isolate themselves at home. Different studies have been initiated that allow us to understand the changes in behaviors related to physical activity and sedentary lifestyle in populations. The objective of this work was the analysis of the importance of physical activity in COVID-19 times. A systematic review was carried out and a questionnaire was applied to the population that performs physical activity in parks of Puebla City, Mexico. The results of the present systematic review suggest that engaging in even light physical activity during the pandemic can help eliminate some of the negative impacts on the health of populations. Since those who experience a decrease in physical activity also have higher levels of stress and anxiety. The data obtained from the questionnaire applied to the study population showed a participation of 54\% men and 46\% women, ages 14-70 years for men and 18-69 years for women. Regarding the time they perform physical activity, men reported 2-3 days (40.74\%), 4-5 days (29.62\%) and $>5$ days (29.62\%), women $2-3$ days (17.39\%), 4-5 days (52.17\%) and $>5$ days (30.43\%). Regarding the time that men spend sitting $<3$ hours $(14.81 \%), 4-8$ hours $(70.37 \%)$ and $>8$ hours $(14.81 \%)$, women $<3$ hours $(13.04 \%), 4-8$ hours $(65.21 \%)$ and $>8$ hours $(21.73 \%)$. The variables of practiced time of physical activity, days a week, minutes a day and hours sitting between men and women showed no significant difference $(\mathrm{P}>0.05)$. It is recommended that populations get involved in physical activities in order to maintain a better quality of life and thus mitigate the phenomena associated with confinement due to the pandemic.
\end{abstract}

Keywords: Physical activity; COVID-19; Public health; Pandemic; Questionnaire

\section{Introduction}

A global pandemic caused by the new coronavirus (COVID-19) resulted in restrictions on daily life, including social distancing and the closure of recreational facilities in cities and provinces, national parks and playgrounds. Confinement and social distancing caused by COVID-19 can influence public health. The unprecedented global confinement, with severe standards of confinement, may have changed physical activity and sedentary habits due to prolonged stays at home $[1,2]$.

The COVID-19 pandemic led to physical isolation measures in many parts of the world. Global restrictions include staying home, unless seeking medical attention, providing care, buying food, exercising, or attending work in an essential service. All undergraduate college classes switched to online learning, primarily at home [3].

This coronavirus pandemic has imposed unprecedented restrictions on people's physical activity and routines. Prolonged stays at home can lead to states of fear, panic, anxiety and depression, which in turn can lead to a reduction

\footnotetext{
* Corresponding author: Antonio Rivera

Centro de Investigaciones en Ciencias Microbiológicas de la Benemérita Universidad Autónoma de Puebla, México.
} 
in active lifestyles. Therefore, determining the psychological response in the general population and the level of influence of the development of physical activity at home could be relevant during this exceptional period of quarantine for COVID-19 disease [4].

The COVID-19 pandemic requires the application of strict isolation strategies to slow the spread of the virus. However, the isolation of people in combination with fear of contagion, quarantine and stigma, as well as a possible overload of (bad) information ("infodemic"), causes chronic stress and is associated with a burden for the mental health, which poses risk factors for anxiety and depression. It is well known that chronic stress is an important modulator of immunity and therefore directly influences the probability of infection [5].

Social isolation during the COVID-19 pandemic includes confinement at home, which results in an increase in physical inactivity and sedentary behaviors, favoring physical deconditioning [6]. Physically deconditioned people have metabolic and systemic alterations due to lack of movement, as well as poor eating practices, consumption of alcohol and tobacco. The objective of this work was the analysis of the importance of physical activity in COVID-19 times.

\section{Material and methods}

\subsection{Search strategy}

The development of this study was through the survey, identification, selection and analysis of the scientific production carried out based on the following criteria: 1) publications in article format; 2) publications resulting from empirical studies; 3) publications referring to the period from January 2020 to January 2021; 4) publications available in the electronic databases SCIELO and MEDLINE/PUBMED.

The search descriptors in the Spanish and English language were adopted on the following terms "physical activity" and "COVID-19", and their corresponding scientific terms identified in the Descriptors in Health Sciences (DeCS), of the Pan American Organization of Health and the Medical Subject Headings (MeSH), of the National Library of Medicine, of the National Institutes of Health of the United States.

The selection of the articles was carried out by two researchers independently, first analyzing the title and abstract of the different studies; the articles that met the eligibility criteria were analyzed in full text to confirm their relevance [7]. The eligibility criteria in this review were related to articles published in English and Spanish, related to our study objective that identified "physical activity" and "COVID-19", theses and scientific articles of systematic review were excluded.

\subsection{Questionnaire}

After a review of the literature, a group of multidisciplinary scientists and academics designed the questionnaire "Habits of physical activity in times of pandemic" (RPATP-COVID19) ". The survey was applied to 500 people who go to perform physical activity in outdoor parks in Puebla City, Mexico, during the period from January to February 2021. A survey was designed to analyze the habits of practicing physical activity and lifestyle in order to know the keys to the importance of physical activity [8,9]. The questions were presented in a written format and applied in person, with questions related to sociodemographic and physical activity issues.

\subsection{Statistical analysis}

The variables of practiced time of physical activity, days a week, minutes a day and hours sitting, were analyzed with the chi-square test, with a $\mathrm{P}<0.05$ significance value (INSTAT GraphPad-Software).

\section{Results}

\subsection{Description of reviewed studies}

The search in the different databases yielded 223 articles related to the descriptors "COVID-19" and "physical activity", the duplicate articles, excluded and selected in the qualitative analysis are presented in the flow diagram (Figure 1). 


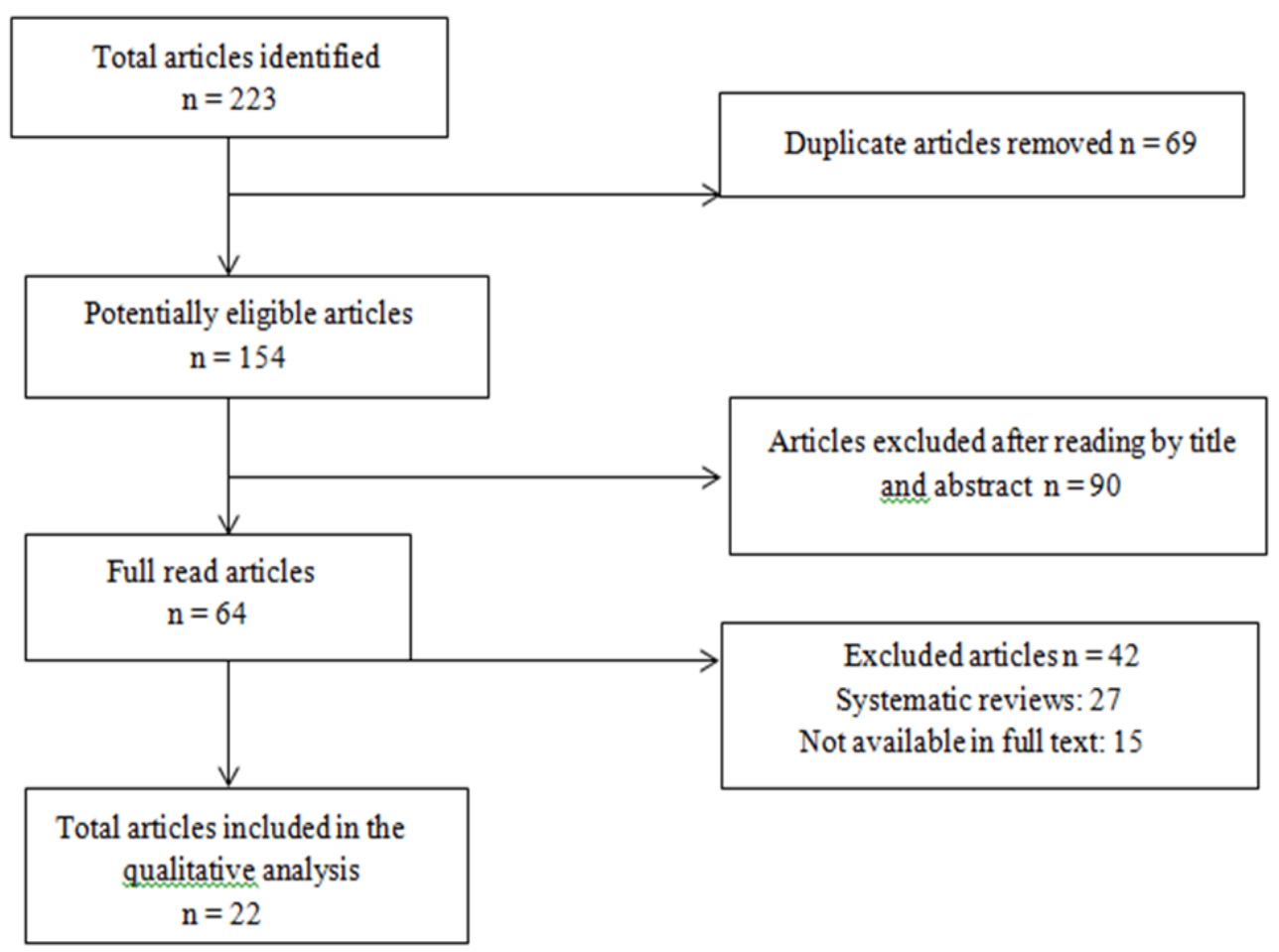

Figure 1 Flow diagram of study selection process.

Among the most outstanding topics of the material obtained in the databases, the following were presented: confinement, depression, anxiety, stress, sleep habits, tobacco, alcohol, pulmonary rehabilitation, sedentary lifestyle, obesity, changes in diet, risk of disease cardiovascular, processed food consumption, immune response, impact of social isolation and mental health. Only the studies $(n=22)$ that highlighted "physical activity" and "COVID-19" were included and their analysis allowed us to know the following trends that involve the importance of doing physical activity in COVID-19 times (Table 1).

Analysis of the papers included in this review showed the following highlights: Participants reported levels of moderate and vigorous physical activity, sitting time, and screen time before and after COVID-19. The current public health guidelines, stress, loneliness, positive mental health, social connection, and symptoms of depression and anxiety were self-reported. They reported $\geq 8$ hours / day of sitting. Overall, $62 \%$ of the participants were women, aged 18-24 years. Physical activity was lower after COVID among participants who reported being previously active, but virtually unchanged among previously inactive participants. Self-isolation / quarantine was associated with increased symptoms of depression and anxiety. Maintaining and improving participation in physical activity and limiting increases in screen time during abrupt social changes can mitigate the consequences for mental health [10].

The physical and psychological consequences of this unexpected scenario could be especially worrisome for people over 60 years of age. This study aims to examine the psychological well-being of older adults during home isolation due to the COVID-19 pandemic and to investigate whether compliance with the World Health Organization global recommendations on physical activity for health is associated with their resilience, affection, and depressive symptoms. The results showed that older adults who regularly participated in vigorous physical activity and moderate-vigorous physical activity during their forties reported higher scores on resilience, positive affect, and fewer symptoms of depression [11].

In a sample of participants of both sexes between 18-62 years, showed an increase in body weight, which was positively associated with the consumption of fried foods $\geq 3$ times a week, low water consumption and sedentary time $\geq 6 \mathrm{~h} /$ day. Daily alcohol consumption was associated with decreased physical activity. Eating habits, physical activity, and active rest can be protective factors for weight gain during COVID-19 confinement [12]. 
Table 1 Main characteristics studies.

\begin{tabular}{|c|c|c|c|c|c|c|c|}
\hline Authors & $\begin{array}{l}\text { Setting of } \\
\text { target } \\
\text { population }\end{array}$ & $\begin{array}{l}\text { Study } \\
\text { desing }\end{array}$ & $\begin{array}{l}\text { Sample } \\
\text { size }\end{array}$ & $\begin{array}{l}\text { Age } \\
\text { range }\end{array}$ & Gender/Sex & Population & Recruitment \\
\hline $\begin{array}{l}\text { Meyer,2020 } \\
{[10]}\end{array}$ & United States & Transversal & $\mathrm{n}=3052$ & $\begin{array}{l}18-24 \\
\text { years }\end{array}$ & $\begin{array}{l}F=1892 \\
M=1160\end{array}$ & $\begin{array}{l}\text { General } \\
\text { population }\end{array}$ & Online survey \\
\hline $\begin{array}{l}\text { Carriedo,2020 } \\
\text { [11] }\end{array}$ & Spain & Transversal & $\mathrm{n}=483$ & $\begin{array}{l}60-92 \\
\text { years }\end{array}$ & - & $\begin{array}{l}\text { General } \\
\text { population }\end{array}$ & Online survey \\
\hline $\begin{array}{l}\text { Reyes,2020 } \\
{[12]}\end{array}$ & Chile & Transversal & $\mathrm{n}=700$ & $\begin{array}{l}18-62 \\
\text { years }\end{array}$ & $\begin{array}{l}F=528 \\
M=172\end{array}$ & $\begin{array}{l}\text { General } \\
\text { population }\end{array}$ & Inquiry \\
\hline $\begin{array}{l}\text { Martinez,2020 } \\
{[13]}\end{array}$ & Spain & Longitudinal & $\mathrm{n}=693$ & - & - & $\begin{array}{l}\text { General } \\
\text { population }\end{array}$ & Online survey \\
\hline $\begin{array}{l}\text { Schmidt,2020 } \\
{[14]}\end{array}$ & Germany & Longitudinal & $\mathrm{n}=1711$ & $\begin{array}{l}4-17 \\
\text { years }\end{array}$ & - & $\begin{array}{l}\text { General } \\
\text { population }\end{array}$ & Inquiry \\
\hline $\begin{array}{l}\text { Schuch,2020 } \\
{[15]}\end{array}$ & Brazil & Transversal & $\mathrm{n}=937$ & - & $\begin{array}{l}F=674 \\
M=263\end{array}$ & $\begin{array}{l}\text { General } \\
\text { population }\end{array}$ & Inquiry \\
\hline $\begin{array}{l}\text { Callow, } 2020 \\
{[16]}\end{array}$ & $\begin{array}{l}\text { United States } \\
\text { and Canada }\end{array}$ & $\begin{array}{l}\text { Descriptive } \\
\text { transversal }\end{array}$ & $\mathrm{n}=1046$ & $\begin{array}{l}>\quad 50 \\
\text { years }\end{array}$ & - & $\begin{array}{l}\text { General } \\
\text { population }\end{array}$ & Online survey \\
\hline $\begin{array}{l}\text { Duncan,2020 } \\
{[17]}\end{array}$ & United States & Transversal & $\mathrm{n}=3971$ & - & $F=3971$ & Adult twins & Online survey \\
\hline $\begin{array}{l}\text { Galle,2020 } \\
{[18]}\end{array}$ & Italy & Transversal & $\mathrm{n}=1430$ & $\begin{array}{l}20-26 \\
\text { years }\end{array}$ & $\begin{array}{l}F=930 \\
M=500\end{array}$ & $\begin{array}{l}\text { Univesrity } \\
\text { students }\end{array}$ & Online survey \\
\hline $\begin{array}{l}\text { Suzuki,2020 } \\
{[19]}\end{array}$ & Japan & Transversal & $\mathrm{n}=165$ & $\begin{array}{l}70-86 \\
\text { years }\end{array}$ & - & Seniors & Questionnaires \\
\hline $\begin{array}{l}\text { Yamada,2020 } \\
{[20]}\end{array}$ & Japan & Longitudinal & $\mathrm{n}=800$ & $\begin{array}{l}69-79 \\
\text { years }\end{array}$ & $\begin{array}{l}F=400 \\
M=400\end{array}$ & Seniors & Online survey \\
\hline $\begin{array}{l}\text { Lopez- } \\
\text { Sanchez,2021 } \\
{[21]}\end{array}$ & Spain & Longitudinal & $\mathrm{n}=160$ & $\begin{array}{l}18-64 \\
\text { years }\end{array}$ & $\begin{array}{l}F=113 \\
M=47\end{array}$ & $\begin{array}{l}\text { General } \\
\text { population }\end{array}$ & Online survey \\
\hline $\begin{array}{l}\text { Vancini,2020 } \\
\text { [22] }\end{array}$ & Brazil & Transversal & - & - & - & $\begin{array}{l}\text { General } \\
\text { population }\end{array}$ & Online survey \\
\hline $\begin{array}{l}\text { Phillipou,2020 } \\
\text { [23] }\end{array}$ & Australia & Transversal & $\mathrm{n}=5469$ & - & - & $\begin{array}{l}\text { General } \\
\text { population }\end{array}$ & Online survey \\
\hline $\begin{array}{l}\text { Yang,2020 } \\
{[24]}\end{array}$ & China & Transversal & $\mathrm{n}=10000$ & $\begin{array}{l}12-20 \\
\text { years }\end{array}$ & - & $\begin{array}{l}\text { High school } \\
\text { and } \\
\text { Undergraduate } \\
\text { students } \\
\end{array}$ & Social media \\
\hline $\begin{array}{l}\text { Martinez,2020 } \\
{[25]}\end{array}$ & Brazil & Transversal & $\mathrm{n}=1613$ & - & - & $\begin{array}{l}\text { General } \\
\text { population }\end{array}$ & Online survey \\
\hline $\begin{array}{l}\text { Rowlands,2021 } \\
{[26]}\end{array}$ & $\begin{array}{l}\text { United } \\
\text { Kindom } \\
\end{array}$ & Transversal & $\mathrm{n}=91248$ & - & - & $\begin{array}{l}\text { General } \\
\text { population }\end{array}$ & BioBank \\
\hline $\begin{array}{l}\text { Qi,2020 } \\
{[27]}\end{array}$ & China & Transversal & $\mathrm{n}=645$ & - & - & $\begin{array}{l}\text { General } \\
\text { population }\end{array}$ & Online survey \\
\hline $\begin{array}{l}\text { Browne,2020 } \\
{[28]}\end{array}$ & $\begin{array}{l}\text { Not } \\
\text { mentioned }\end{array}$ & $\begin{array}{l}\text { Linear } \\
\text { mixed } \\
\text { models }\end{array}$ & $\mathrm{n}=35$ & $\begin{array}{l}>\quad 60 \\
\text { years }\end{array}$ & - & $\begin{array}{l}\text { General } \\
\text { population }\end{array}$ & - \\
\hline $\begin{array}{l}\text { Pombo,2020 } \\
{[29]}\end{array}$ & Portugal & Transversal & $\mathrm{n}=2159$ & $\begin{array}{l}<\quad 13 \\
\text { years }\end{array}$ & - & Children's & $\begin{array}{l}\text { Anonymous } \\
\text { survey }\end{array}$ \\
\hline $\begin{array}{l}\text { Crochemore- } \\
\text { Silva,2020 } \\
{[30]}\end{array}$ & Brazil & $\begin{array}{l}\text { Cross- } \\
\text { sectional } \\
\text { descriptive } \\
\end{array}$ & $\mathrm{n}=377$ & $\begin{array}{l}>\quad 20 \\
\text { years }\end{array}$ & - & $\begin{array}{l}\text { General } \\
\text { population }\end{array}$ & Not mentioned \\
\hline $\begin{array}{l}\text { Brady,2021 } \\
\text { [31] }\end{array}$ & $\begin{array}{l}\text { United } \\
\text { Kindom }\end{array}$ & Transversal & $\mathrm{n}=345$ & $\begin{array}{l}>\quad 50 \\
\text { years }\end{array}$ & - & $\begin{array}{l}\text { General } \\
\text { population }\end{array}$ & Online survey \\
\hline
\end{tabular}


Confinement had a significant differential effect on the physically active participants, who experienced a significant decrease in their levels of physical activity, sleep quality, and well-being; while the physically inactive participants did not experience significant changes. The findings of this longitudinal study indicate that a period of lockdown due to COVID-19 had a negative impact on levels of physical activity, quality of sleep and well-being in a group of physically active Spanish adults. Public health authorities should be aware that people who tend to lead an active lifestyle may be particularly susceptible to these disorders [13].

In youth ages 4-17 before and during the strictest time of the first COVID-19 lockout, they showed that sports activity decreased while recreational screen time increased. However, a substantial increase in usual physical activities leads to an overall increase in physical activity among children and adolescents in Germany. The effects differ in size but not in direction between age groups and are stable for boys and girls. They suggest that physical activity among children and adolescents is highly context-dependent and mutual and does not act as a functional opposite to screen time [14].

Associations between moderate to vigorous physical activity and sedentary behavior with depressive symptoms were evaluated in Brazilians who self-isolated during the COVID-19 pandemic. Those who engaged in $\geq 30$ minutes/day of moderate to vigorous physical activity or $\geq 15$ minutes/day of vigorous physical activity were less likely to have depressive and anxiety symptoms. Those who spent $\geq 10$ hours / day sedentary were more likely to have depressive symptoms [15].

Adults over the age of 50 living in North America who engaged in higher levels of physical activity experienced lower levels of depression-like symptoms. A hierarchical regression analysis that incorporated the intensity of physical activity performed (light, moderate and vigorous) in the model indicated that more light and non-moderate activity predicted lower symptoms of depression [16].

It has been established that physical distancing and other mitigation strategies from the COVID-19 pandemic can have unintended consequences on various health behaviors. However, different studies have shown that a perceived decrease in physical activity or exercise is associated with higher levels of stress and anxiety [17].

A study carried out on Italian students showed that all sedentary behaviors increased significantly and all physical activities decreased significantly during the confinement. Time spent using electronic devices showed the greatest increase and walking the greatest decrease. The practice of adequate physical activity during the confinement was mainly associated with the previous adoption of an active lifestyle. The promotion of active lifestyles during the nonpandemic period may have had positive effects also in the event of closure [18].

Public health restrictions were observed to affect physical activity in the elderly, especially those who had higher levels of exercise / sports activity and lower health-related quality of life prior to COVID-19 [19].

When the changes in physical activity in older adults living in communities in Japan were investigated, it was observed that due to the COVID-19 epidemic, the total time of physical activity decreased significantly. This finding may lead to a higher incidence of disability in the near future in older people [20].

The study that analyzed physical activity levels in a sample of quarantined adults with chronic diseases showed that there was a significant decrease in moderate intensity physical activity in the participants. In addition, there was a significant decrease in vigorous-intensity physical activity in men with chronic diseases and in those with multimorbidity [21].

A study carried out in Brazil showed that the participants who had symptoms of COVID-19 had the highest percentage of level 1 of physical activity (the lowest level according to the classification used) and those who did not present symptoms had the highest percentage of levels 2 and 3 of physical activity. It is possible to assume that the regular practice of physical activity could positively impact the state of health and quality of life and be a tool in the field of public health to face (from the physical and mental point of view) disease scenarios requiring quarantine [22].

The work that sought to identify changes in eating and exercise behaviors in an Australian sample between people with an eating disorder and the general population, amid the pandemic outbreak of COVID-19 showed that the group of eating disorders, were found increased restriction behaviors, bingeing, purging, and exercise. In the general population, both increased restrictive behaviors and binge-eating were reported; however, respondents reported less exercise compared to before the pandemic [23]. 
The study that aimed to assess changes in obesity and activity patterns among young people in China during the COVID19 shutdown showed that the average body mass index of all young participants increased significantly. There were also increases in the prevalence of overweight / obesity in youth in general, especially in high school and undergraduate students. Their activity patterns had also changed significantly, including decreased frequency of participating in active transportation, moderate / vigorous-intensity household chores, moderate / vigorous-intensity physical activity in leisure time, and leisure-time walks, and increased sedentary activity, sleep, and screen time [24].

Physical inactivity and sedentary behavior are associated with poor physical and mental health. Changes in the habits of the Brazilian participants who perform physical activities in relation to their practices were evaluated, due to social distancing measures during the COVID-19 epidemic in 2020.79.4\% reported that the measures to contain the epidemic had some impact on their physical activities and many had to interrupt or decrease the frequency of their practices. Participants who felt a greater impact of the quarantine on their physical activities tend to have a higher prevalence of symptoms of anxiety and depression. Individuals who practiced physical activities reported that social distance had a great influence on their practices. Furthermore, changes in these habits are associated with high levels of poor mental health [25].

We investigated whether the balance of physical activity and sleep/rest were associated with SARS-CoV-2 positivity and severity. The results highlight the importance of not only physical activity, but also quality sleep/rest and regular sleep / rest patterns, on the risk of COVID-19 [26].

Participation in physical activity, health-related quality of life, and levels of perceived stress were explored among Chinese adults during the COVID-19 pandemic. Participants reported an increase in sedentary time from the pre-COVID19 period to the COVID-19 pandemic period. More than half of the participants (53\%) reported moderate levels of stress. Significant correlations were observed between participation in physical activity and levels of perceived stress. Prolonged sitting time was also found to have a negative effect on health-related quality of life. During such periods of home confinement, public health strategies aimed at educating Chinese adults to improve physical activity at home may be necessary to maintain health at the population level [27]. Furthermore, the COVID-19 pandemic can cause unhealthy changes in movement behavior in hypertensive older adults [28].

The time allotted for physical activity during the COVID-19 pandemic was documented to be reduced compared to what was routinely reported on normal days. Strategies need to be found to increase children's physical activity, especially in families where both parents are working and have no outdoor space [29].

The study that analyzed physical activity in leisure time during the COVID-19 pandemic in a municipality in the state of Rio Grande do Sul, southern Brazil, according to sex, level of education and adherence to social distancing, showed marked inequalities. The prevalence of leisure-time physical activity among men was 20 percentage points higher than women and 40 percentage points higher among those with more education than among those with less education [30].

Nationwide lockdowns during the pandemic can compromise mental health and psychological well-being and limit opportunities for physical activity, particularly in clinical populations, such as people with rheumatoid arthritis, who are considered at risk for complications from COVID-19. Associations between physical activity and sedentary time with mental health and well-being were examined. Sedentary time was positively associated with physical fatigue. These findings show the importance of encouraging physical activity for people with rheumatoid arthritis during a period of lockdown for mental health and well-being [31].

\subsection{Questionnaire data}

Five hundred people who attended different public parks in Puebla City, Mexico, were surveyed during the period from January to February 2021. Of the total number of respondents $(n=500), 54 \%$ were men and $46 \%$ women. The reported ages ranged from 14 to 70 years for men and from 18 to 69 years for women (Figure 2). 


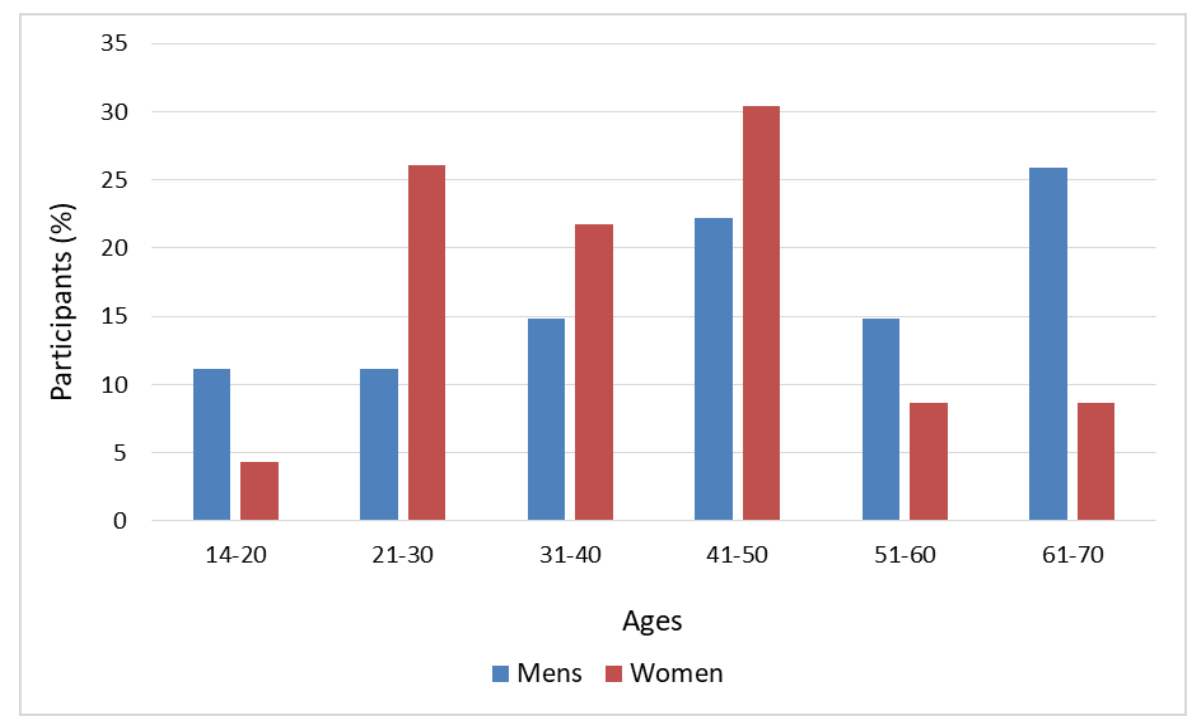

Figure 2 Mens and women distribution with respect to ages.

Regarding the time they have practicing physical activity, the following data were reported: men with a time $<1$ month $(18.51 \%)$ and a time $>12$ months (81.49\%), women reported with $<1$ month (8.69\%), of 1 to 6 six months (8.69\%) and $>12$ months $(82.62 \%)$.

From the information referring to the days they dedicate to the practice of physical activity, the following data were obtained: the men reported that 2 to 3 days (40.74\%), 4 to 5 days (29.62\%) and $>5$ days (29.62\%). For their part, women mentioned that 2 to 3 days (17.39\%), 4 to 5 days $(52.17 \%)$ and $>5$ days $(30.43 \%)$.

When reviewing the minutes they dedicate per day to physical activity, the following information was obtained: from 10 to 30 minutes (3.70\%), 30 to 60 minutes (66.66\%) and $>60$ minutes $(29.62 \%)$ for men. For women 10 to 30 minutes (4.34\%), 30 to 60 minutes $(65.21 \%)$ and $>60$ minutes (30.43\%).

From the information regarding the state of their physical health, the following was obtained: the men reported as bad (3.70\%), fair (40.74\%) and good (55.55\%). Women reported as bad (4.34\%), fair (30.43\%) and good (65.21\%).

In the area related to sedentary lifestyle, the number of hours they spend sitting per day was asked, the following data were presented: men $<3$ hours (14.81\%), 4 to 8 hours $(70.37 \%)$ and $>8$ hours $(14.81 \%)$. Women $<3$ hours $(13.04 \%), 4$ to 8 hours $(65.21 \%)$ and $>8$ hours $(21.73 \%)$.

The reason why men perform physical activity reported that for health (85.17\%) and for competition (14.83\%), women for health (91.30\%) and for competition (8.70\%).

The variables of practiced time of physical activity, days a week, minutes a day and hours sitting between men and women showed no significant difference $(\mathrm{P}>0.05)$.

\section{Discussion}

The total number of articles $(\mathrm{n}=223)$ related to the descriptors "physical activity" and "COVID-19", $\mathrm{n}=22$ articles that followed the approach established in the selection guides were included in the qualitative analysis [32]. During the selection process, different study topics related to the descriptors established for this work were observed, highlighting those referring to public health and their effects on social confinement. Hence the importance of the present investigation, with the understanding that based on health security policies refers to the health contingency to avoid the contagion of COVID-19, confinement was chosen, which brings with it a decrease in physical mobility and body movement is concerned, with this lower energy expenditure and consequently a progressive decrease in physical capacities and abilities that make up the physical performance of the human being. Therefore, considering that to have a better quality of life it is important to attend to the level of physical health which is part of physical well-being and for this it is required to maintain certain standards of physical activity, physical exercise and physical conditioning, according to the opportunity and decision of each individual [33]. 
Therefore, a culture of care and timely organization of physical activity in the different stages of the human being will favor the healthy physical state of the individual, in the situation of remaining in confinement and without a regimen or orientation of pertinent physical activity; there is the latent risk of significantly compromising the overall health of the individual [34].

Of the surveys that were applied $(n=500)$ in different public parks in the city of Puebla, Mexico, a higher percentage of men (54\%) was observed, compared to women (46\%), being a trend that does not observed behaves in the same way in different reports, since in a study carried out in Chihuahua, Mexico, women represented the highest percentage and in a study carried out with students from the National University of La Matanza, Argentina, men represented the highest percentage $[35,36]$.

It is relevant to note that women who perform physical activity in the age range 21-50 years represented 78.24\%, being higher than men with $48.14 \%$. For their part, men who perform physical activity in the range of 51-70 years represented $40.73 \%$ compared to $16.18 \%$ in women, the above is related to the physiological conditions experienced by women compared to men in adulthood greater, while considering the importance of physical activity in disease prevention [3739].

Therefore, optimal well-being is achieved through the combination of good physical activity habits, a balanced diet, and prudent rest. In addition to the above, personal responsibility for the care or prevention of minor illnesses must be incorporated, as well as knowing when professional medical attention is needed. However, just as in timely medical care, there must be timely physical activity care, and in times of pandemic, it is a good time to do so and acquire a culture of physical activity, only then are results and benefits achieved with a relationship positive and significant on physical health and consequently a necessary mental health in these times [40].

Regarding the time they have been practicing physical activity, the time they spend per week / minutes, the data are variable with respect to what has been reported in studies prior to the pandemic [13]. And in the area related to sedentary lifestyle there is a correspondence with the increase in the time spent without physical activity [10].

In this specific attention to prevent the spread of contagion by COVID-19, important attention must also be given to physical well-being, both current and future, since reflection leads us to that from now on everything related to health will be oriented towards preventive and primary care either in the private or public sectors [41].

Regarding the realization of physical activity, it is important to emphasize that once it is decided to do it, it must be considered without respite that it be guided by qualified personnel since they will be careful to prescribe, advise and moderate optimally, always attending and observing the pedagogical and methodological principles of the prescription of exercise and physical conditioning, since it is required that the components of the physical load be observed, such as: type of exercise, duration of the exercise, intensity, number of exercises carried out, frequency in perform them, as well as the progression once the body's adaptations to the execution process begin and continue over time [42].

\section{Conclusion}

Finally, considering the most appropriate type of exercise in times of pandemic, we must not forget that attending to the physical strength of the body puts us on the sidelines of strengthening the quality of life, however if what is proposed is to favor prevention systems in the acquisition of diseases airways, one of the most recommended types of exercise will be moderate intensity aerobic exercise since it is emerging as the most optimal to avoid an aggravation of symptoms or signs that affect the airways, since its main adaptation will be closely linked to these tissues of the cardiorespiratory system and at the same time strengthen the immune system.

\section{Compliance with ethical standards}

\section{Acknowledgments}

The authors thank our institutions for the facilities granted to carry out this research, and to the coordinators of the sports parks of the government in Puebla City, Mexico.

\section{Disclosure of conflict of interest}

None reported. 


\section{Statement of informed consent}

Informed consent was obtained from all individual participants included in the study.

\section{References}

[1] Lesser IA, Nienhuis CP. The Impact of COVID-19 on physical activity behavior and well-being of Canadians. Int J Environ Res Public Health. 2020; 17(11): 3899.

[2] Castañeda-Babarro A, Arbillaga-Etxarri A, Gutiérrez-Santamaría B, Coca A. Physical activity change during COVID-19 confinement. Int J Environ Res Public Health. 2020; 17(18): 6878.

[3] Gallo LA, Gallo TF, Young SL, Moritz KM, Akison LK. The impact of isolation measures due to COVID-19 on energy intake and physical activity levels in Australian University students. Nutrients. 2020; 23; 12(6): 1865.

[4] Camacho-Cardenosa M, Merellano-Navarro E, Trapé AA, Brazo-Sayavera J. Influence of physical activity during outbreak on psychological states in adults in the Covid-19 pandemic: a study protocol. Rev Esp Salud Publica. 2020; 12; 94: e202006063.

[5] Burtscher J, Burtscher M, Millet GP. (Indoor) isolation, stress, and physical inactivity: Vicious circles accelerated by COVID-19?. Scand J Med Sci Sports. 2020; 30(8): 1544-1545.

[6] Mera-Mamián AY, Tabares-Gonzalez E, Montoya-Gonzalez S, Muñoz-Rodriguez DI, Monsalve-Vélez F. Practical recommendations to avoid physical deconditioning during confinement due to pandemic associated with COVID19. Universidad y Salud. 2020, 22(2): 166-177.

[7] Moher D, Schulz KF, Simera I, Altman DG. Guidance for developers of health research reporting guidelines. PLoS Med. 2010; 7: e1000217.

[8] Castillo E, Abad MT, Giménez FJ, Robles J. Designing a questionnaire on physical activity habits and lifestyle from the Delphi method. Revista de Ciencias del Deporte. 2012; 8(1): 51-66.

[9] Mantilla TSC, Gómez-Conesa A. International physical activity. An adequate instrument in population physical activity monitoring. Rev Iberoam Fisioter Kinesol. 2007; 10(1): 48-52.

[10] Meyer J, McDowell C, Lansing J, Brower C, Smith L, Tully M, Herring M. Changes in physical activity and sedentary behavior in response to COVID-19 and their associations with mental health in 3052 US adults. Int J Environ Res Public Health. 2020; 17(18): 6469.

[11] Carriedo A, Cecchini JA, Fernandez-Rio J, Méndez-Giménez A. COVID-19, psychological well-being and physical activity levels in older adults during the nationwide lockdown in Spain. Am J Geriatr Psychiatry. 2020; 28(11): 1146-1155.

[12] Reyes-Olavarría D, Latorre-Román PA, Guzmán-Guzmán IP, Jerez-Mayorga D, Caamaño-Navarrete F, DelgadoFloody P. Positive and negative changes in food habits, physical activity patterns, and weight status during COVID-19 confinement: Associated factors in the Chilean population. Int J Environ Res Public Health. 2020; 28; 17(15): 5431.

[13] Reyes-Olavarría D, Latorre-Román PA, Guzmán-Guzmán IP, Jerez-Mayorga D, Caamaño-Navarrete F, DelgadoFloody P. Positive and negative changes in food habits, physical activity patterns, and weight status during COVID-19 confinement: Associated factors in the Chilean population. Int J Environ Res Public Health. 2020; 28; 17(15): 5431.

[14] Schmidt SCE, Anedda B, Burchartz A, Eichsteller A, Kolb S, Nigg C, Niessner C, Oriwol D, Worth A, Woll A. Physical activity and screen time of children and adolescents before and during the COVID-19 lockdown in Germany: a natural experiment. Sci Rep. 2020; 10(1): 21780.

[15] Schuch FB, Bulzing RA, Meyer J, Vancampfort D, Firth J, Stubbs B, Grabovac I, Willeit P, Tavares VDO, Calegaro VC, Deenik J, López-Sánchez JF, Veronese N, Caperchione CM, Sadarangani KP, Abufaraj M, Tully MA, Smith L. Associations of moderate to vigorous physical activity and sedentary behavior with depressive and anxiety symptoms in self-isolating people during the COVID-19 pandemic: A cross-sectional survey in Brazil. Psychiatry Res. 2020; 292: 113339.

[16] Callow DD, Arnold-Nedimala NA, Jordan LS, Pena GS, Won J, Woodard JL, Smith JC. The mental health benefits of physical activity in older adults survive the COVID-19 pandemic Am J Geriatr Psychiatry. 2020; 28(10): 10461057. 
[17] Duncan GE, Avery AR, Seto E, Tsang S. Perceived change in physical activity levels and mental health during COVID-19: Findings among adult twin pairs. PLoS One. 2020; 15(8): e0237695.

[18] Gallè F, Sabella EA, Ferracuti S, De Giglio O, Caggiano G, Protano C, Valeriani F, Parisi EA, Valerio G, Liguori G, Montagna MT, Spica VR, Da Molin G, Orsi GB, Napoli C. Sedentary behaviors and physical activity of Italian undergraduate students during lockdown at the time of CoViD-19 pandemic. Int J Environ Res Public Health. 2020; 17(17): 6171.

[19] Suzuki Y, Maeda N, Hirado D, Shirakawa T, Urabe Y. Physical activity changes and its risk factors among community-dwelling japanese older adults during the COVID-19 epidemic: Associations with subjective wellbeing and health-related quality of life. Int J Environ Res Public Health. 2020; 10; 17(18): 6591.

[20] Yamada M, Kimura Y, Ishiyama D, Otobe Y, Suzuki M, Koyama S, Kikuchi T, Kusumi H, Arai H. Effect of the COVID19 epidemic on physical activity in community-dwelling older adults in Japan: A cross-sectional online survey. J Nutr Health Aging. 2020; 24(9): 948-950.

[21] López-Sánchez GF, López-Bueno R, Gil-Salmerón A, Zauder R, Skalska M, Jastrzębska J, Jastrzębski Z, Schuch FB, Grabovac I, Tully MA, Smith L. Comparison of physical activity levels in Spanish adults with chronic conditions before and during COVID-19 quarantine. Eur J Public Health. 2021; 31(1): 161-166.

[22] Vancini RL, Camargo-Neto L, Claudio, de Lira CAB, Andrade MS, Viana RB, Nikolaidis PT, Knechtle B, Gentil P, Piacezzi LHV, Lopes MCBT, Batista REA, Vancini-Campanharo CR. Physical activity and sociodemographic profile of Brazilian people during COVID-19 outbreak: An online and cross-sectional survey. Int J Environ Res Public Health. 2020; 17(21): 7964.

[23] Phillipou A, Meyer D, Neill E, Tan EJ, Toh WL, Van Rheenen TE, Rossell SL. Eating and exercise behaviors in eating disorders and the general population during the COVID-19 pandemic in Australia: Initial results from the COLLATE project. Int J Eat Disord. 2020; 53(7): 1158-1165.

[24] Yang S, Guo B, Ao L, Yang C, Zhang L, Zhou J, Jia P. Obesity and activity patterns before and during COVID-19 lockdown among youths in China. Clin Obes. 2020; 10(6): e12416.

[25] Martinez EZ, Silva FM, Morigi TZ, Zucoloto ML, Silva TL, Joaquim AG, Dall'Agnol G, Galdino G, Martinez MOZ, Silva WRD. Physical activity in periods of social distancing due to COVID-19: a cross-sectional survey. Cien Saude Colet. 2020; 25(suppl 2): 4157-4168.

[26] Rowlands AV, Kloecker DE, Chudasama Y, Davies MJ, Dawkins NP, Edwardson CL, Gillies C, Khunti K, Razieh C, Islam N, Zaccardi F, Yates T. Association of timing and balance of physical activity and rest/sleep with risk of COVID-19: A UK biobank study. Mayo Clin Proc. 2021; 96(1): 156-164.

[27] Qi M, Li P, Moyle W, Weeks B, Jones C. Physical activity, health-related quality of life, and stress among the Chinese adult population during the COVID-19 pandemic. Int J Environ Res Public Health. 2020; 17(18): 6494.

[28] Browne RAV, Macêdo GAD, Cabral LLP, Oliveira GTA, Vivas A, Fontes EB, Elsangedy HM, Costa EC. Initial impact of the COVID-19 pandemic on physical activity and sedentary behavior in hypertensive older adults: An accelerometer-based analysis. Exp Gerontol. 2020; 142: 111121.

[29] Pombo A, Luz C, Rodrigues LP, Ferreira C, Cordovil R. Correlates of children's physical activity during the COVID19 confinement in Portugal. Public Health. 2020; 189: 14-19.

[30] Crochemore-Silva I, Knuth AG, Wendt A, Nunes BP, Hallal PC, Santos LP, Harter J, Pellegrini DDCP. Physical activity during the COVID-19 pandemic: a population-based cross-sectional study in a city of South Brazil. Cien Saude Colet. 2020; 25(11): 4249-4258.

[31] Brady SM, Fenton SAM, Metsios GS, Bosworth A, Duda JL, Kitas GD, Veldhuijzen van Zanten JJCS. Different types of physical activity are positively associated with indicators of mental health and psychological wellbeing in rheumatoid arthritis during COVID-19. Rheumatol Int. 2021; 41(2): 335-344.

[32] Hutton B, Catalá-López F, Moher D. The PRISMA statement extension for systematic reviews incorporating network meta-analysis: PRISMA-NMA. Med Clin (Barc). 2016; 147(6): 262-266.

[33] Smith BJ, Lim MH. How the COVID-19 pandemic is focusing attention on loneliness and social isolation. Public Health Res Pract. 2020; 30; 30(2): 1-4.

[34] Faulkner J, O'Brien WJ, McGrane B, Wadsworth D, Batten J, Askew CD, Badenhorst C, Byrd E, Coulter M, Draper N, Elliot C, Fryer S, Hamlin MJ, Jakeman J, Mackintosh KA, McNarry MA, Mitchelmore A, Murphy J, Ryan-Stewart, Saynor Z, Schaumberg M, Stone K, Stoner L, Stuart B, Lambrick D. Physical activity, mental health and well-being 
of adults during initial COVID-19 containment strategies: A multi-country cross-sectional analysis. J Sci Med Sport. 2020; 24(4): 320-326.

[35] Muñoz-Daw MJ, Muñoz-Duarte M, De La Torre-Diaz ML, Hinojosa-Seáñez E, Pardo_renteria JB. Motivation for practice of recreational physical activity and physical inactivity in populaton of Chihuahua (Mexico), Nutr Clin Diet Hosp. 2016; 36(1): 10-16.

[36] Pérez UG, Laíño FA, Zelarayán J, Márquez S. Actividad física de salud en estudiantes universitarios argentinos. Nutr Hosp. 2014; 30(4): 896-904.

[37] Gyasi RM, Phillips DR, Asante F, Boateng S. Physical activity and predictors of loneliness in community-dwelling older adults: The role of social connectedness. Geriatr Nurs. 2020; 24 (20): 30325-30326.

[38] Bosković K, Gava BP, Grajić M, Madić D, Obradović B, Todorović ST. Adapted physical activity in the prevention and therapy of osteoporosis. Med Pregl. 2013; 66(5-6): 221-422.

[39] Sun F, Norman IJ, While AE. Physical activity in older people: a systematic review. BMC Public Health. 2013; 6(13): 449.

[40] Zhang X, Li X, Sun Z, He Y, Xu W, Campbell H, Dunlop MG, Timofeeva M, Theodoratou E. Physical activity and COVID-19: an observational and Mendelian randomisation study. J Glob Health. 2020; 10(2): 1-9.

[41] Bentlage E, Ammar A, How D, Ahmed M, Trabelsi K, Chtourou H, Brach M. Practical Recommendations for Maintaining Active Lifestyle during the COVID-19 Pandemic: A Systematic Literature Review. Int J Environ Res Public Health. 2020; 28(17): 1-22.

[42] Polero P, Rebollo-Seco C, Adsuar JC, Pérez-Gómez J, Rojo-Ramos J, Manzano-Redondo F, Garcia-Gordillo MA, Carlos-Vivas J. Physical Activity Recommendations during COVID-19: Narrative Review. Int J Environ Res Public Health. 2020; 24: 18(1): 1-24. 